Hydraulic Engineering Repository

Ein Service der Bundesanstalt für Wasserbau

Richardson, Everett V.; Lagasse, Peter F. River Engineering For Highway Encroachments FHWA HDS-6

Verfügbar unter / Available at:

https://hdl.handle.net/20.500.11970/100252

Vorgeschlagene Zitierweise / Suggested citation:

Richardson, Everett V.; Lagasse, Peter F. (2010): River Engineering For Highway Encroachments FHWA HDS-6. In: Burns, Susan E.; Bhatia, Shobha K.; Avila, Catherine M. C.; Hunt, Beatrice E. (Hg.): Proceedings 5th International Conference on Scour and Erosion (ICSE-5), November 7-10, 2010, San Francisco, USA. Reston, Va.: American Society of Civil Engineers. S. 1082-1091. 


\title{
River Engineering For Highway Encroachments FHWA HDS-6
}

\author{
Everett V. Richardson ${ }^{1}$, Ph.D., P.E., Hon.D.WRE \& F. ASCE and \\ Peter F. Lagasse ${ }^{2}$. Ph.D., P.E., D.WRE \& F. ASCE
}

${ }^{1}$ Senior Associate, Ayres Associates Inc, and Professor Emeritus Colorado State Univ. ${ }^{2}$ Senior Vice President, Ayres Associates Inc, 3665 JFK Parkway, Ft. Collins, CO 80525

\begin{abstract}
In the 1960's Frank Johnson, Chief of the Hydraulics Branch of the Federal Highway Administration, and Regional FHWA Hydraulic Engineers were concerned that State, Federal and Consulting Engineers were not cognizant of the interaction between highway crossings and encroachments and the river environment. As a result, FHWA funded the development of a manual and training course in 1975, which was revised in 1990. In 2001 the manual was revised and issued as FHWA HDS-6. HDS-6 has chapters giving the fundamentals of open channel flow; alluvial channel flow; sediment transport; geomorphology and river morphology; river stabilization and bank protection; scour at bridges; data needs and sources; design considerations; and examples of real design and evaluation problems. There are 646 pages, 231 figures, and 425 references in HDS-6. The course has been given 45 times to over 1,100 highway engineers. This paper summarizes the chapters in HDS6 and the history of the manual and training course.
\end{abstract}

\section{INTRODUCTION}

In 1975 the U.S. Federal Highway Administration published a manual entitled "Highways in the River Enviorment (HIRE) - Environmental and Hydraulic Considerations" (Richardson et al, 1975) and established a one week training course for Federal and State Highway Engineers. The manual and training course resulted from the concerns of Carl Izzard, Les Herr, Frank Johnson and FHWA Hydraulic Engineers, that highway engineers did not have the knowledge and background to properly evaluate the threat to bridges and encroachments from stream instability and scour, to evaluate the environmental consequences that highway bridges and encroachments had on streams and rivers or the knowledge to alleviate or diminish these consequences. To alleviate this problem, Frank Johnson, Chief Hydraulic Engineer, FHWA, selected Colorado State University, with Dr. Everett Richardson as PI, to produce a manual and training course for the National Highway Institute. The selection was based on CSU's experience in river engineering, fluvial geomorphology, sediment transport and scour research and CSU's contribution of Drs. Everett V. Richardson and Daryl B. Simon's time.

The 1975 manual, written by E.V. Richardson, D.B. Simons, S. Karaki, M. A. Stevens, and K. Mahmood from 1973 to 1975, contains eight chapters. 1) Introduction, 2) Open Channel Flow, 3) Fundamentals of Alluvial Channel Flow, 4) Fluvial Geomorphology, 5) River Mechanics, 6) River Stabilization, 7) Needs and Sources of Data, and 8) Hydraulic and Environmental Considerations of Highway River Crossing and Encroachments. 
Each author wrote a chapter, which was reviewed, added to and refined by the others. However, Richardson and Simons finalized the manual. FHWA Hydraulic Engineers Frank Johnson, Murray L. Cory, Dah-Cheng Woo, Milo Cress, Lawrence J. Harrison, Herbert Gregory and Gene Fiala and Mainard Wacker (Wyoming Highway Department) and Roger L. Dean (FHWA-NHI) served as a steering committee. They meet with Richardson and Simons quarterly to review, add to and critic the manual and course. Steering Committee members took one of the first two courses along with State Bridge Engineers to finalize the course. Graduate Students Peter F. Lagasse, V. M. Ponce, Larry Runquest and Tony Melone assisted the authors in writing the manual and instructing the first two courses, which were two weeks long, including a field trip to observe grade control structures on Sand Creek in Denver, Colorado.

In 1990 Richardson and Pierre Julian (Richardson et al, 1990) revised the manual adding new material. In 2001 at the request of Philip L. Thompson, Chief Hydraulic Engineer, FHWA, the manual was extensively revised by Lagasse and Richardson (Richardson et al, 2001) and published as FHWA Hydraulic Design Series Number 6 entitled "River Engineering for Highway Encroachments Highways in the River Environment."

The HIRE training course was given by Drs. E.V. Richardson and D.B. Simons 45 times in the period 1974 to 1998. It was given in 23 States and Puerto Rico and to over 1,100 highway engineers and officials. The course is number FHWA-NHI-135010 in NHI (2010) catalog.

HDS-6 has eleven (11) chapters and three (3) appendixes, There are 646 pages, 231 figures, and 425 references. A glossary defines 277 words or terms that are used by river and highway engineering professionals. The manual uses dual units (SI and English). Example problems are solved and several case studies are given derived from actual river engineering for highway encroachments problems completed by the authors. The Publication No. is FHWA NHI 01-004. It is available from the NATIONAL TECHNICAL INFORMATION SERVICE, Springfield, VA 22161, (703) 4874650 , isddc.dot.gov.

\section{RIVER ENGINEERING FOR HIGHWAY ENCROCHMENTS FHWA HDS-6 Chapter 1. Introduction}

The chapter lays the foundation for the manual, by briefly classifying river crossings and encroachments. The dynamics of rivers, the affects of highway construction on river systems and affects of river development on highway crossings and encroachments are given. A brief review of the contents of each chapter is given.

\section{Chapter 2. Open Channel Flow}

The fundamental fluid mechanics of rigid boundary one-dimensional open channel flow are described. Rigid boundary open channel flow has no deformation of the bed or banks, whereas, in mobile boundary hydraulics the bed and banks can and do change (scour and fill). In text book style the three basic equations (conservation 
of mass, momentum and energy) are derived. Shear stress, velocity distribution, average velocity and the relation between shear stress and velocity for steady uniform flow are derived. The Manning and Chezy average velocity equations and the relation between them are given as are Tables for Manning's $\mathrm{n}$.

Unsteady flow conditions are described and equations are derived or given to determine the relations between boundary conditions, velocity, discharge or depth. The unsteady flow conditions are gravity waves (deep or shallow water), surges, roll waves, steady rapidly varying flow (transitions, specific energy and discharge diagrams), super critical flow transitions, flow over drop structures, flow in bends, and gradually varied flow (water surface profiles).

Stream Gaging. The methods for measuring instantaneous, daily and annual flow of rivers and streams are described. Typical gaging stations, stage/time hydrographs and stage/discharge graphs are illustrated. Also, the USGS velocity/sub-area flow measurement method to determine discharge $(\mathrm{Q})$ is described.

\section{Chapter 3. Fundamentals of Alluvial Channel Flow}

This chapter covers properties of alluvial material and methods of measuring these properties, sediment grade scale, flow in sand-bed channels, classification and prediction of bed forms, Manning's $\mathrm{n}$ for sandbed and other natural streams, how bed form changes affect highways in the river enviorment, beginning of motion, flow in coarse bed streams, critical velocity to move stones, Shields beginning of motion figures and physical measurement of sediment discharge in the field. The equation and figures to determine sediment particle fall velocity and a figure (Figure 1) for angle of repose of non-cohesive material is given. Four example problems are solved in dual units.

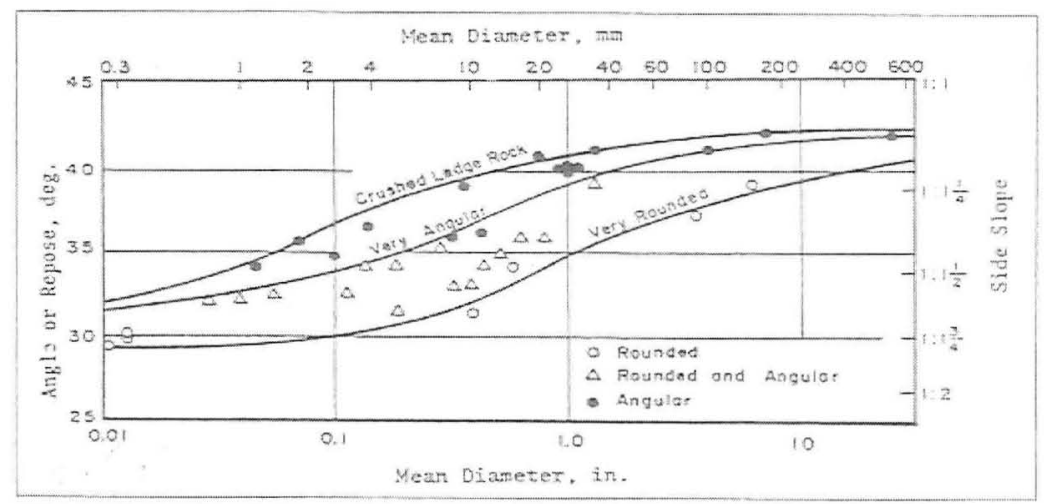

Figure 1. Angle of repose of non-cohesive materials (Richardson et al, 1975).

Based on the research of Simons and Richardson (1963, 1966), (Guy, et al, 1966), Richardson (1965), Richardson et al, (1962), (Richardson and Simons (1967), 
the regimes of flow, associated bed forms, sediment transport and resistance to flow (Manning's n) for alluvial sand bed streams are described in detail. These regimes of flow and associated bed forms are given in Figure 2. Resistance to flow in the lower flow regime is high (Manning's n 0.020 to 0.04 ) and bed material transport is low (less than 2,000 ppm). In the upper flow regime Manning's $\mathrm{n}$ ranges from 0.012 to 0.020 and sediment transport is large (greater than 2,000 ppm). Bed form in an alluvial sand channel depends on bed material fall velocity, which depends on particle size and water viscosity; depth of flow; flow velocity and slope of the energy grade line. With changes in depth (discharge), water viscosity (water temperature), or both the bed form can go from the lower flow regime to the upper flow regime or the reverse. This can result in a discontinuous stage/discharge relations (Beckman and Furness (1962), (Nordin, 1964), (Dawdy, 1961); changes in Manning's $n$ and depth in navigation channels (U.S. Army Corps of Engineers (1968) and Manning's n and depth in major rivers (Figure 3).

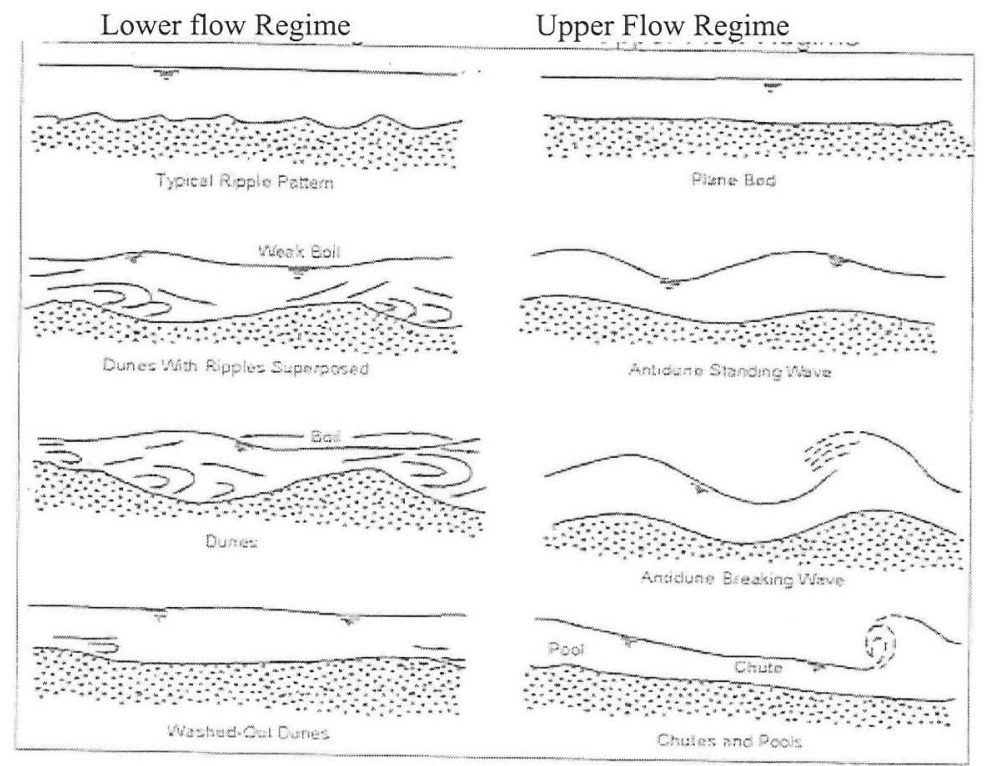

Figure 2. Bed forms in sand channels (Simons and Richardson 1963, 1966). 


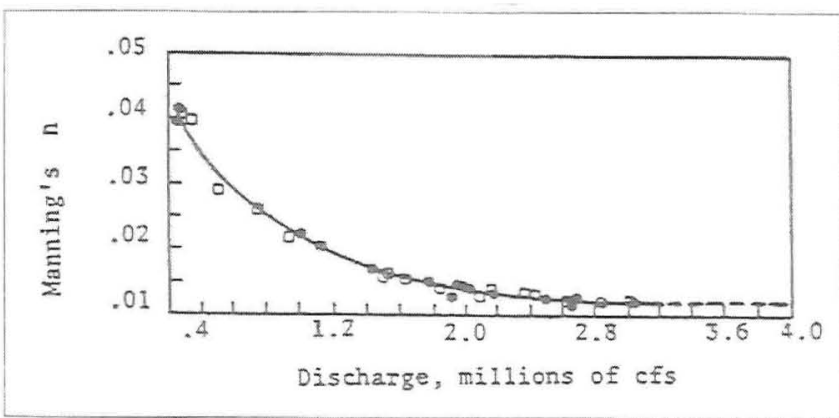

Figure 3. Change in Manning's $\mathrm{n}$ with discharge, Padma River in Bangladesh. (Richardson et al, 1975)

\section{Chapter 4. Sediment Transport}

Total sediment discharge at a cross section of a stream is the sum of the bed material discharge (commonly called bed load) and the fine sediment discharge (Einstein's (1950) wash load). Bed material discharge (bed load) is the discharge of the sediments that are in the bed and is transported at the capacity of the hydraulic conditions of the stream. Fine sediment discharge (wash load) is the sediment discharge of sediments not found in appreciable quantities in the bed. It comes from the watershed, washes through the section, and is usually not transported at the capacity of the stream. In the literature, using the term load to describe sediment discharge evolved because sediment discharge is expressed as tons per unit of time (tons per day for example).

HDS-6 defines total sediment transport by type of movement (contact load and suspended load); by method of measurement (measure load and unmeasured load): and by source of the sediment (wash load and bed material load). We prefer the use of sediment discharge for load but the literature is ingrained with load.

Chapter four defines the various terms used to describe and measure total sediment discharge. It defines suspended sediment discharge and develops Rouse's classic suspended sediment distribution equation. The Meyer-Peter and Muller (1948), Einstein's (1950), and Yang's (1996) equation and methods to compute bed material discharge (bed load) are included. Colby's (1964) method (using a figure giving the relation between sand bed discharge and mean velocity) for estimating bed material discharge and power functions for calculating bed material discharge are also given. Example problems are worked to illustrate the calculations.

\section{Chapter 5. River Morphology and River Response}

Streams (rivers, creeks, etc.) may be meandering, braided, or relatively straight. They may have flood plains. They may flow in mountains, on piedmonts, be tidal, on deltas or alluvial fans. They may have nickpoints or have headcutting. Their flow may be ephemeral or perennial. At a given location, streams can change significantly with time. For example, a stream on an alluvial fan may be entrenched, 
fairly straight and stable but in time may shift to a multiple channel, braided and unstable stream. All these morphology factors affect a highway crossing or encroachment. Also, a highway crossing or encroachment may affect or change the morphological factors.

HDS-6 describes river morphology for highway engineers so they can anticipate how a highway crossing or encroachment affects the river and how rivers affect his crossing or encroachment. Chapter 5 is based on the authors' field experience and knowledge of the literature on fluvial geomorphology. It describes how rivers affect highways and highways affect rivers. Papers by Davis (1899), Lane (1957), Leopold et al (1953, 60, 64), Schumm (1968, 72, 77, 81) Schumm et al, (1976, 98), Thorn (1997) and others are used and many figures and tables are included. For example, Brice and Blodgett's (1978) figure classifying rivers as to size, bed material, sinuosity and ten other characteristics and the Culberson et al (1967) classification are given together with descriptions of how these classification affect river crossings or encroachments. The Shen et al (1981) classification figure relating stream stability to river form and sediment transport is given and discussed. Meander characteristics of bends, crossings, point bars, alternate bars, concave and convex banks, radius of curvature and width and wave length are discussed together with recommendations of how to measure, alter, stabilize or design meander stream reaches.

Physical and mathematical hydraulic computer models available for the highway engineer are given. The chapter objective is to aid the highway engineer in understanding the role that fluvial geomorphology, river morphology, and river changes and response to change have in highway design, inspection and maintenance. Example problems are given.

\section{Chapter 6. River Stabilization and Bank Protection}

Many types and methods of river control and bank stabilization methods have evolved over the years to control the short and long term changes that were described in Chapter 5. Concrete, brick, willow, rock, and asphalt mattresses; sacked concrete; riprap; grouted riprap; sheet and timber piles; steel jack and brush jetties; angled and sloped rock-filled, earth-filled, riprapped and timber dikes or spurs; and concrete armor units are used for training, restoring and stabilizing rivers .

This chapter describes the causes of bank erosion and failure and river stabilization measures. It describes and gives design recommendations for flow control structures such as spurs for lateral control and drop structures for vertical control. The descriptions and design recommendations include riprap: bioengineering countermeasures; effects of canalization; channel restoration and rehabilitation; and overtopping of roadways. Problems to determine the design of riprap in SI and English units are solved.

To determine the size of rock for embankment slopes, the riprap stability factor design equation that was first developed by Stevens (Stevens and Simons, 
$1971)$ is developed. This is followed with the U.S. Army Corps of Engineers design equation (Maynord, 1988) along with the Corps charts and figures as design guides. Riprap gradation, thickness, filters and placement methods are described.

The use of and design of rock enclosed wire mattresses (gabions); soil cement, rock, sand, and earth filled sacks; and articulated concrete blocks to control bank erosion of erosion from roadway overtopping flows are described.

\section{Chapter 7. Scour at Bridges}

The four components that the design, maintenance and inspection of highway crossings and encroachments must address to ensure their safety from erosion (scour) are described. These are 1) long-term degradation or aggradation; 2) general scour (contraction scour); 3) local scour at piers and abutments; and 4) stream movement. Clear-water and live-bed scour conditions defined. Equations are given for contraction and local scour at piers and abutments. The original CSU equation for pier scour is discussed, as is the latest equation given in FHWA HEC-18 (Richardson and Davis, 2001). The reader is referred to latest FHWA manuals, HEC-18 (Richardson and Davis, 2001), HEC-20 (Lagasse et al, 2001) and HEC-23 (Lagasse et al, 2009), for a more comprehensive coverage of scour, stream stability and countermeasures for the design and inspection of highway crossings and encroachments. Also, to ASCE Compendium entitled "Stream Stability and Scour at Highway Bridges (Richardson and Lagasse, 1999).

\section{Chapter 8. Data Needs and Data Sources}

An extensive list of the data needed and the sources of data for the design and evaluation of a highway crossing or encroachment are given. Reference to computerized literature and data is given. For example, Transportation Research Board's TRIS computer program. The list is very extensive and all the items listed may not be needed for a given highway crossing or encroachment problem. Therefore, a check list is provided for the engineer to check what data is needed and to check off when it has been obtained.

\section{Chapter 9. Design Considerations for Highway Encroachments and Crossings}

This chapter presents the application of the fundamentals of hydraulics, hydrology, fluvial geomorphology, and river mechanics to the hydraulic and environmental design and evaluation of highway river crossings and encroachments. Both short-term and long-term design and evaluation of highways in the river environment are delineated. Conceptual and actual examples are described.

A three level analysis procedure for the design or evaluation of a highway crossing or encroachment is recommended: 1) simple geomorphic and qualitative analysis, 2) advanced geomorphic and quantitative engineering analysis, 3) mathematical or physical model studies. The method begins with broad considerations and proceeds through a series of steps of increasing complexity to narrow down to the final design or evaluation conclusion. Many projects are finished at Level Two, but a complex or costly project may need Level Three. These 
levels are described in detail in HDS-6 and FHWA'S HEC-18, HEC-20, and HEC 23.

Local, upstream and downstream affects of the bridge or encroachment on a river or a river on the crossing or encroachment are illustrated using conceptual and actual field examples. Hydraulic, geomopholgical and environmental design and evaluation of sixteen river crossings or encroachments by highway engineers are given. In presenting the course, time is allotted to this chapter to allow students to present their hydraulic and fluvial geomorphology highway problems for discussion.

\section{Chapter 10. Design Examples of Highways in the River Environment}

Three examples are given in detail illustrating the application, methods and concepts of the previous chapters to the design or evaluation of highway encroachments and crossings. The designs or evaluation use the three level approach described in Chapter 9. They use the geomorphic, hydrologic, and hydraulic and river mechanics principles to design safe and economical crossing that protect, maintain and restore the river enviorment.

\section{Chapter 11. References}

The 425 references that were reviewed and used in the preparation of HDS- 6 are given in this chapter.

\section{Appendixes}

There are three appendixes. A) Metric system, conversion factors and water properties, B) Analysis of selected sediment transport relationships and C) Index. The eleven sediment transport relationships that are evaluated in Appendix B are: 1) Ackers and White; 2) Bagnold; 3) Brownlie; 4) Einstein; 5) Karim; 6) Karim and Kennedy; 7) Laursen; 8) Shen and Hung; 9) Toffaletti; and Yang'73 and '84. They were evaluated as to their applicability for size of sediment (gravel, coarse sand, fine sand or silt) and size of river (small intermediate or large).

\section{CONCLUSION}

In the early 1970's the Federal Highway Administration produced a training manual and course titled "Highways in the River Environment -Hydraulic and Environmental Considerations." In 1990 the manual was revised to include new material. In 2001 it was extensively revised and published as SDS-6. The contents of HDS-6, which are summarized in this paper, are fundamentals of open channel flow, alluvial channel flow; sediment transport; geomorphology and river morphology, river stabilization and bank protection, scour at bridges; data needs and sources, design considerations, and examples of real design and evaluation problems. The training course has been given 45 times in 23 States and Puerto Rico and to over 1,100 highway engineers.

\section{REFERENCES}

Beckman, M.A. and Furness, L.W. (1962). "Flow Characteristics of Elkhorn River near Waterloo, Nebraska." USGS WSP 1498-B, Reston, VA, 34 p. 
Brice, J.C. and Blodgett, J.C. (1978). "Countermeasures for Hydraulic Problems at Bridges." Vol. 1, Analysis and Assessment." FHWA-RD-78-162. Vol. 2 "Countermeasures for Hydraulic Problems at Bridges. Case Histories for Sites 1-283," FHWA-RD-78163, FHWA, Washington, D.C.

Colby, B.R. (1964). "Practical Computations of Bed-Material Discharge." ASCE Hydr. Div., Jour., Vol. 90, No. HY2.

Culbertson, D.M., Young, L.E., and Brice, J.C. (1967). "Scour and Fill in Alluvial Channels," USGS Open File Report, Reston, VA.

Dawdy, D.R. (1961). "Depth-Discharge Relations of Alluvial Streams - Discontinuous Rating Curves." USGS WSP 1498-C, Reston, VA. 16p.

Davis, W.M. (1999). "The Geographical Cycle." Geographical Journal, 14, pp. 481-504.

Einstein, H.A. (1950). "The Bed Load Function for Sediment Transportation in Open Channel Flows." U.S. Dept. of Agriculture, SCS, Tech. Bull. 1026.

FHWA NHI (2010). "Improving the Performance of the Transportation Industry Through Training." Catalog. Washington, D.C.

Guy, H.P., Simons, D.B. and Richardson, E.V. (1966). "Summary of Alluvial Channel Data From Flume Experiments, 1956-61," USGS Professional Paper 462-I, Reston, VA.

Lagasse, P.F., Schall, J.D. and Richardson, E.V. (2001). "Stream Stability at Highway Structures." HEC-20, 3 Ed, FHWA NHI 01-002.

Lagasse, P.F., Clopper, P.E., Pagan-Ortez, J.E, Zevenbergen, L.W., Arneson, L.A., Schall, J.D. and Girard, L.G. (2009). "Bridge Scour and Stream Instability Countermeasures - Experience, Selection, and Design Guidelines." HEC-23, 3 Ed, NHI 09-111.

Lane, E.W. (1957). "A Study of the Shape of Channels Formed by Natural Streams Flowing in Erodible Material." Missouri River Div. Sed. Series No. 9, U.S. Army Corps of Engineers, Omaha, NE.

Leopold, L.B. and Maddock, Jr., T. (1953). "The Hydraulic Geometry of Stream Channels and Some Physiographic Implications." USGS Prof. Paper 252, Reston, VA, 57p.

Leopold, L.B. and Wolman, M.G., (1960). "River Meanders." Geol. Soc. Am. Bull., V 71.

Leopold, L.B., Wolman, M.G., and Miller, J.B. (1964). "Fluvial Processes in Geomorphology." W. H. Freeman and Co., San Francisco, CA.

Maynord, S.T. (1988). "Stable Riprap Size for Open Channel Flows," Tech. Report HL-884, U.S. Army Corps of Engineers, Washington, D.C.

Nordin, C.F. (1964). "Aspects of Flow Resistance and Sediment Transport, Rio Grande near Bernalillo, New Mexico." USGS WSP 1498-4, 41 p.

Meyer-Peter, E. and Müller, R. (1948). "Formulas for Bed-Load Transport." Proc. 3d Meeting IAHR, Stockholm, pp. 39-64.

Richardson, E.V. (1965). "Resistance to Flow in Sand Channels." Ph.D. Dissertation, Colorado State University, Fort Collins, CO, Results incorporated into USGS Prof. Paper 422-J, Reston, VA.

Richardson, E.V., Simons, D.B., and Haushild, W.L. (1962). "Boundary Form and Resistance to Flow in Alluvial Channels." Inter. Assoc. of Hydr. Res., Belgium.

Richardson, E.V. and Simons, D.B. (1967). "Resistance to Flow in Sand Channels." Proc. XII Cong. Inter. Assoc. Hydr. Res., V. 1, No. A18, Fort Collins, CO,

Richardson, E.V., Simons, D.B., Karaki, S., Mahmood, K., and Stevens, M.A. (1975). "Highways in the River Enviorment, Hydraulic and Environmental Design Considerations." U.S. Department of Transportation, FHWA, Washington, D.C.

Richardson, E.V., Simons, D.B. and Julian, P.Y. (1990). "Highways in the River Environment, Hydraulic and Environmental Design Considerations." U.S. Department of Transportation, FHWA, Washington D.C, 
Richardson, E.V., Simons, D.B., and Lagasse, P.F. (2001). "River Engineering for Highway Encroachments - Highways in the River Environment." Federal Highway Administration, Hydraulic Series No. 6, FHWA NHI 01-004, Washington, D.C.

Richardson, E.V. and Lagasse P.F. (eds.) (1999). "Stream Stability and Scour at Highway Bridges." - Comp., Water Resources Eng. Conf. 1991-1998." ASCE, Reston, VA.

Richardson, E.V. and Davis, S.R. (2001). "Evaluating Scour at Bridges, Fourth Edition." HEC-18, FHWA NHI O1-001, Washington, D.C.

Schumm, S.A. (1968). "Speculations Concerning Paleohydrologic Controls of Terrestrial Sedimentation," Geol. Soc. Am. Bull., Vol. 79, pp. 1572-1588.

Schumm, S.A., edit. (1972). "River Morphology." Benchmark Papers in Geology, Dowden Hutchinson \& Ross, John Wiley \& Sons.

Schumm, S.A. (1977). "The Fluvial System." Wiley and Sons, 338 p.

Schumm, S.A. (1981). "Evolution and Response of the Fluvial System." Sedimentologic Implications: SEPM Special Publication 31, p. 19-19.

Schumm, S.A. and Beathard, R.M. (1976). "Geomorphic Thresholds." ASCE Rivers 76, Vol. 1, Reston, VA, pp. 707-724.

Schumm, S.A. and Lagasse, P.F. (1998). "Alluvial Fan Dynamics - Hazards to Highways." ASCE Water Resources Eng, '98, V.1, Reston, VA, pp. 298-303.

Shen, H.W., Schumm, S.A., Nelson, J.D., Doehring, D.O., Skinner, M.M., and Smith, G.L. 1981. "Methods for Assessment of Stream Related Hazards to Highways and Bridges." FHWA/RD-80/160, FHWA, Washington, D.C.

Simons, D.B. and Richardson, E.V. (1963). "Forms of Bed Roughness in Alluvial Channels." ASCE Trans., Vol. 128, pp. 284-323.

Simons, D.B. and Richardson, E.V. (1966). "Resistance to Flow in Alluvial Channels. USGS Prof. Paper 422-J, Reston, VA, 61 p.

Stevens, M.A. and Simons, D.B. (1971). "Stability Analysis for Course Granular Material on Slopes." River Mechanics, H.W. Shen, ed., WRP, Littleton, CO.

Stevens, M.A., Simons, D.B., and Richardson, E.V. (1984). "Riprap Stability Analysis." Proc. Second Bridge Eng. Conf. Minneapolis, MN, Transportation Research Board, No. 950 TRB, NRC, Washington, D.C.

Thorne, C.R., Hey, R.D., and Newson, M.D., (eds) (1997). "Applied Fluvial Geomorphology for River Engineering and Management." John Wiley, NY.

U.S. Army Corps of Engineers (1968). "Missouri River Channel Regime Studies." MRD Sediment Series No. 13A, Omaha, NE.

Yang, C.T. (1996). "Sediment Transport Theory and Practice." McGraw-Hill Companies, Inc. 